\title{
Financialization with Chinese characteristics? Exchanges, control \& capital markets in authoritarian capitalism ${ }^{1}$
}

\author{
Johannes Petry \\ Johannes Petry, Department of Politics and International Studies, University of Warwick \\ (j.petry@warwick.ac.uk)
}

\begin{abstract}
A growing body of research has analyzed the variegation of financialization processes and the role of states as important actors therein. Contributing to this literature, this paper argues that more than important actors facilitating financialization, states can also (partially) exert control over, actively manage and shape financialization. In the context of China's variegated financialization process, this paper analyzes the crucial role of securities exchanges in the development of China's capital markets since the global financial crisis 2007-09. These state-owned exchanges act as intermediaries between the Chinese state, society and finance by shaping the infrastructural arrangements of capital markets. Thereby, they facilitate the authorities' ability to control markets and direct their outcomes towards state policies. Financialization is thereby decoupled from a neoliberal policy paradigm, and rather than a break with China's authoritarian capitalism, exchanges facilitate state control within and through financialization.

Keywords: China; financialization; capital markets; securities exchanges; authoritarian capitalism; market infrastructures.
\end{abstract}

\section{Introduction}

Since the global financial crisis 2007-2009 (GFC), capital markets have gradually become an important pillar of China's socio-economic system of authoritarian capitalism. During the Third Plenary Session of the $18^{\text {th }}$ National Congress of the Chinese Communist Party in 2013, the Chinese government officially declared that markets had a 'decisive role' to play in allocating resources and facilitating growth in the Chinese economy, a position that was reaffirmed during the $19^{\text {th }}$ Congress in 2017 . With the ongoing process of Reform and Opening as well as the rebalancing of China's economy towards internal consumption, the service sector and investment-driven growth, the authorities decided to give finance a leading role for national development.

\footnotetext{
${ }^{1}$ Pre-print version of the article accepted for publication in Economy \& Society.
} 
Consequently, the financial sector expanded rapidly in recent years. Between 2003-2006 and 2014-2017, the average total value of stocks traded increased from 27.2 to 193.2 per cent of GDP, market capitalization of listed domestic companies almost tripled from 28 to 67 per cent of GDP, while the ratio of market- versus bank-based activity increased from 0.2 to $1.09^{1}$ (World Bank, 2018). From less than 5 per cent in 2002, securities market financing by Chinese firms increased to 30 per cent of Total Social Financing by 2016 (Gabor, 2018; Lu and Sweeney, 2012), while China's derivative markets grew from accounting for $<1$ per cent of global futures trading in 2002 to 16 per cent in 2016 (FIA, 2017). Between 2007 and 2015, the financial sector's contribution to GDP almost doubled from 5 to 9 per cent (Huang and Lardy, 2016). By 2017, China's capital markets had become the $2^{\text {nd }}$ largest stock markets, $2^{\text {nd }}$ largest futures markets and $3^{\text {rd }}$ largest bond markets in the world.

Such processes of capital market development are often described as important characteristics of financialization processes. And while not yet on par with highly financialized economies such as the United States, ${ }^{2}$ it becomes clear that 'many phenomena of financialization [are] observable in China' (Pauls, Andreosso-O'Callaghan, \& Gottwald, 2016, p. 45), - and that capital markets have become a crucial part in China's political economy, contributing to the increasing financialization of China's authoritarian capitalism (Dal Maso, 2015; Gruin, 2019b; J. Wang, 2017; Y. Wang, 2015). Within the literature on financialization, two bodies of research have emerged around the variegation of financialization processes (Karwowski and Stockhammer, 2017) and the role of states as important actors in facilitating financialization, not only in advanced but also in developing economies (Rethel and Thurbon, 2019). Contributing to these literatures on variegated financialization and the state, this paper argues that more than an important actor in facilitating financialization, the state can also exercise a considerable degree of control over financialization processes and thereby shape their very form. While finance in China is expanding and permeating evermore aspects of economic and political life, in this financialization with Chinese characteristics the authorities try to actively manage financialization to achieve developmental goals. Importantly, this is not done through brute force or command-and-control mechanisms, but through 'pivotal points' in market infrastructures that enable the management and steering of financialization processes.

Therefore, this paper analyzes the crucial role of China's state-owned securities exchanges in the development and management of Chinese capital markets between 2009-2019. More than just marketplaces, as providers of market infrastructures exchanges are themselves powerful actors that exercise considerable influence over capital markets. The paper argues that while China's capital markets have rapidly developed in recent years, they function differently from and fulfil a different role than 'global' capital markets whose primary function is to enable the generation of private profit and who often supersede state logic and constrain state power. What can instead be observed in China is that exchanges act as intermediaries between the Chinese state, 
society and finance by actively managing capital markets. Thereby, they facilitate the state's ability to control capital markets and to direct market outcomes towards the accomplishment of certain state policies that aim to perpetuate China's authoritarian capitalism. While the exchanges' control over capital markets is neither absolute nor always effective, this paper aims to showcase a different way of thinking about and actively managing capital markets in China where financialization is not necessarily linked to neoliberalism. Rather than a break with China's authoritarian capitalism, the activities of the Chinese exchanges help to sustain and facilitate China's socio-economic system by extending state control within and through capital markets, attempting to shape the financialization of China's political economy in accordance with its authoritarian capitalism. Thereby, this single case study on China's capital market development sheds light on debates about neoliberal convergence, models of capitalism and trajectories of financialization.

Next to financial news coverage and other secondary data, the paper draws on 100 expert interviews conducted in mainland China (in total (46); Shanghai (21), Beijing (14), other (11)), Hong Kong (39), Frankfurt (6), London (5) and Singapore (4) between June 2017 and October 2019. These interviews were conducted with exchanges (53 per cent), investors (15 per cent), brokers (11 per cent) and other actors ( 21 per cent) such regulators or clearing houses mainly working in international departments (25 per cent), business development (19 per cent), senior management (18 per cent), research/strategy (14 per cent) or product development (12 per cent). Interviews were conducted with mainland Chinese (46 per cent) Western (41 per cent), Hong Kong (11 per cent) and other Asian (2 per cent) institutions, while a larger proportion of interviewees came from mainland China (57 per cent; in contrast to 10 per cent, 26 per cent and 7 per cent from Hong Kong, Western and other Asian countries, respectively). These interviews provide important insights into how Chinese exchanges manage capital markets, often involving window guidance and informal practices, that cannot be gained from document or dataset analyzes but only through in-depth fieldwork. The broad interview data sample enables cross-checking the narratives of interviewees from different positions within China's capital markets. Consequently, the practices observed in this study are corroborated by multiple interview sources and financial news coverage and regulation (if possible). Further, this triangulation of interview data also prevents individual narratives to bias the analysis.

The paper is structured as followed. After this introduction, the existing literature on (variegated) financialization and the state is discussed, and how China's variegated financialization is anchored in its socio-economic system of authoritarian capitalism which enables the partial steering of financialization processes (section 1). This is then demonstrated in the following sections which analyze how exchanges manage capital markets with respect to different aspects of China's socio-economic system and direct them: to prevent overspeculation in markets (section 2, financial sector); to stabilize the socio-political system (section 3 , society); for finance to serve 
the real economy (section 4, national development); to assist in the reform and restructuring of China's companies (section 5, non-financial sector); and maintaining control despite an integration with global markets (section 6). Section 7 concludes.

\section{Financialization with Chinese characteristics: capital markets, state control and market management practices}

The development of capital markets has been a core focus of financialization research. For Epstein (2005, p. 3), financialization 'means the increasing role of financial motives, financial markets, financial actors and financial institutions in the operation of the domestic and international economies', while Pike and Pollard (2010, p. 30) define financialization as the 'growing influence of capital markets, their intermediaries and processes in economic and political life'. Other scholars also attribute a significant role to capital markets in financialization processes, be it in the dissemination of marketbased financial activities and practices (Aglietta and Breton, 2001), the rise of shareholder value-oriented corporate governance (Williams, 2000), or 'the increased ability to trade risk' (Hardie, 2012). At the heart of and as a precondition of many aspects of financialization stand capital markets and their development. This is not only the case when it comes to financialization in advanced economies, but also with respect to the study of financialization in developing and emerging economies (see Bonizzi, 2013). This literature highlights that financialization processes are not uniform, they are rather variegated and refracted by national institutional settings that lead to different trajectories of financialization (Dixon, 2011; Karwowski and Stockhammer, 2017). As Lapavitsas and Powell (2013, p. 359) emphasized, "both the form and the content of financialization vary according to institutional, historical and political conditions in each country'. This has also been picked up in debates about the relationship between financialization and the state. Previously, many scholars argued that financialization often results in a relative loss of state power vis-à-vis finance (Strange, 1998) and the effects on developing economies are often described as potentially negative with financialization for instance decreasing their borrowing capacity and thereby policy space (Hardie, 2012) or deepening existing power asymmetries between states (Bortz and Kaltenbrunner, 2018). But stemming from earlier discussions on transformations of the developmental state, more recent scholarship has highlighted that financial market development has often been actively facilitated by states (Thurbon, 2016). It argues that an increasing hybridization of financialization processes takes place in which state and (quasi-)state institutions often co-constitute financialization processes (see Rethel and Thurbon, 2019).

Contributing to the growing literatures on variegated financialization and the state, this paper argues that states are not only important actors facilitating financialization but can also exercise a considerable degree of control over 
financialization, thereby shaping its very form. Instead of a financialization process that follows a neoliberal logic and constrains state power (Carroll and Jarvis, 2014), what we see in China is a 'financialization with Chinese characteristics' where the state actively tries to manage financialization and its social outcomes.

As a result, the authorities attempt to exercise and maintain their power both within and through the financialization processes that unfold within China's socioeconomic system of authoritarian capitalism. With the transition from plan to market, new market-based calculations and strategies have emerged for exercising state governance (Sigley, 2006). Since the beginning of reforms, China's authoritarian capitalism has relied on both socialist authoritarian practices (e.g. the nomenklatura system) and market-based practices (Sum, 2019; Tsai, 2015). And as discussed, since the GFC, finance has become an ever more important channel to govern the economy as the Chinese authorities have actively facilitated financial development in China's opening up and liberalization strategy and more broadly the transformation of its political economy (Collins and Gottwald, 2014; Gruin, 2019a; Li, 2018a). While financial markets are growing in importance, this occurs within the context of China's socioeconomic system of authoritarian capitalism in which the Chinese Communist Party (CCP) aims to maintain its control over socio-economic development, in part by managing policy uncertainties through the financial sector. Hereby, one can observe an 'exten[sion of] the reach of financial capital, but simultaneously consolidating the persistently illiberal authority of the CCP over the use of that capital' (Gruin, 2016, p. 27).

It is important to note that China's financialization is not a uniform but a variegated process unfolding across nearly every aspect of economic life. From P2Plending (J. Wang, 2018), the shadow banking sector (Tsai, 2015), corporate governance (Y. Wang, 2015), the financialization of everyday investors (Dal Maso, 2015), management practices (Chong, 2018), real estate (Theurillat, Lenzer, \& Zhan, 2016) to the social credit scoring system (Gruin, 2019b). Some aspects of this variegated financialization unfold outside of government control, sometimes initially outside of the purview of the authorities, temporarily tolerated or even actively encouraged by them (J. Wang, 2017). However, at some point the authorities often attempt to reign in developments that are deemed socially counterproductive - prominent examples include the clampdown on developers in the wake of the housing bubble (Yang, 2017) or the deleveraging of the shadow banking sector and attempts to shift these activities towards capital markets (Gabor, 2018).

This steering of financialization processes stems from a fundamentally different understanding of finance in China than in the Western world. While the usefulness of market-based mechanisms for resource allocation and economic coordination has been recognized and facilitated, the authorities also see the downsides of free financial markets after experiencing several financial scandals domestically in the 1990s as well as intensely studying financial crises and their social and political impacts on other states 
and societies (e.g. in post-USSR Russia, Japan). ${ }^{3}$ As McNally (2013, pp. 38-39) argues, there is a 'considerable distrust of markets and full-out economic liberalization', therefore the authorities engage in a 'pragmatic use' of markets, managing markets for specific policy goals. The authorities attempt to steer financialization, as their rule relies on the support of a growing middle class and the promise of continuous economic growth (Heurlin, 2016) - which can both be achieved but also hindered by financial markets.

By analysing the role of exchanges in organising Chinese stock and derivative markets, this paper demonstrates how the Chinese authorities attempt to partially control financialization processes, not through command-and-control measures but by utilising exchanges as 'pivotal points' through which they manage and steer capital markets. Rather than looking at processes of market reform or creation, this paper focuses on practices of market management. Through an analysis of the policies and practices of exchanges in managing capital markets, we can gain insights in how Chinese authorities aim to steer China's variegated financialization process. ${ }^{4}$ Thereby, capital markets can be understood as a site where the authorities exercise 'statecraft [through] financial control' which enables them to govern social and economic life (Sum, 2019, p. 386). Control in this context should be understood both as exerting control within financialization by monitoring, regulating and intervening into capital markets, as well as exerting control through financialization by directing capital market outcomes towards the accomplishment of certain economic and political objectives linked to state policies.

Instead of mere platforms on which market transactions take place, exchanges are powerful actors in their own right who actively organize and shape capital markets (see Ahrne, Aspers, \& Brunsson, 2015; Castelle et al., 2016; Petry, 2020; Wójcik, 2012). Rather than investors who are active within a market, exchanges play a much more architectural role for capital markets as they create the infrastructural arrangements that enable the functioning of these markets (on market infrastructures, see Bernards and Campbell-Verduyn, 2019). As MacKenzie (2006, p. 13) states, 'markets' infrastructures matter', which he defines as 'the social, cultural, and technical conditions that make [financial markets] possible'. By deciding the 'rules of the game' and acting as gatekeepers, deciding who gets in, what is traded and how trading is conducted, exchanges are crucial to shaping capital markets. From market data and indices, listing/creation and trading of various securities, commodities and derivatives, to posttrading activities such as central clearing, settlement, custodian and collateral management services, exchanges are crucial to the functioning of capital markets. Therefore, exchanges are important actors that facilitate and shape financialization processes (Petry, 2020).

How exchanges themselves are governed and by whom they are owned matters a lot for the kind of markets that they are creating. In most advanced economies, exchanges are publicly traded companies, subject to the laws of the market, and they 
have to make profitable business decisions to increase shareholder value and serve the global investment community. But in contrast to being 'marketized', exchanges in China are rather 'politicized'. They are government agencies, subordinated to the China Securities Regulatory Commission (CSRC) or the People's Bank of China, and ultimately, the Chinese government. The Chinese exchanges also occupy a different position within the financial system itself. While global exchanges are subject to competition, Chinese exchanges are shielded from external competitors, internal competition is limited and they have considerable authority over and within the marketspace - as one interviewee working in a global exchange's China team noted: '[in China] the exchange is at the top of the food chain'. ${ }^{5}$ Personnel exchanges (secondments) between the exchanges and regulators are a common feature of their organizational setup, and exchange CEOs are also appointed by the authorities (see also Heilmann, 2005). ${ }^{6}$ Instead of profit/shareholder value, the performance of exchanges, their personnel and management is measured by their contribution towards policy goals. Hence, the exchanges are embedded within the structures that permeate China's authoritarian capitalism (Lyu, 2015; ten Brink, 2019).

This different institutional setup of exchanges has important consequences for how they manage capital markets. Chinese exchanges thereby fulfil an important role as intermediaries between the Chinese state, society and finance - a role which has gained in importance since the increasing post-GFC growth and importance of China's capital markets. These market management practices are not arbitrary but rather aimed at directing market outcomes to achieving state policies that target different aspects of China's authoritarian capitalism: to decrease financial risk (financial sector); to stabilize the socio-political system through market participation (society); to make finance serve the real economy (national development); and to facilitate political-economic reform processes (listed companies). Further, these mechanisms stay in place despite an increasing inflow of international investors.

This control of capital markets is of course not absolute. Sometimes implemented control efforts fall short of their objectives, regulatory reach is incomplete, there are work-arounds in some areas or policy experimentations fail. ${ }^{7}$ After all, neither the Chinese state nor its central institutions such as the CCP are monolithic or all-mighty entities (ten Brink, 2019). However, even when control is not absolute, what this paper demonstrates is a different way of thinking about capital markets and how they are managed through the Chinese state that results in very different market structures and consequently different societal effects of financialization processes. As the following sections demonstrate, the Chinese exchanges thereby facilitate state control within and through capital markets, facilitating and shaping the financialization of China's political economy in accordance with its system of authoritarian capitalism. 


\section{Risk: preventing overspeculation}

Speculation is an integral part of financialization processes (Hardie, 2012). While all states certainly have the objective to prevent financial risk or 'overspeculation', what sets China apart is the constant intervention into and active management of capital markets through its state-owned exchanges. As one Hong Kong-based Chinese broker noted, 'Chinese markets are the only markets where the exchanges don't encourage speculation; because they are worried about the risk' ${ }^{8}$ In order to minimize financial risk, a monitoring and intervention system was established with a level of regulatory oversight unthinkable in global markets. As Charles Li, CEO of the Hong Kong Exchange (HKEx) stated, 'while Europe is struggling with MiFID II, in China you have MiFID 10'. ${ }^{9}$ The exchanges hereby act as intermediaries between the Chinese state and domestic finance.

There are for instance great differences in how exchanges manage market (data) access as they decide which market data is available to investors and if there are speed or information asymmetries. In global exchanges, market data is available as continuous streams and can be bought with different time delays. This provides advantages for those professional traders who can operate faster trading systems and are able to colocate their servers in exchanges' data centres or get direct market access (DMA), that is to plug directly into exchanges without going through a broker. Thereby, exchanges create financial infrastructures that facilitate high frequency trading (HFT) (Mackenzie, 2018). In contrast, in Chinese stock markets, market data only comes as snapshots (2-4 times per second), while DMA or co-location are not allowed. As a result, no speed asymmetries exist between investors and transaction volumes are decreased. In futures markets, HFT is allowed but restricted. While co-location is possible, DMA is not, so that every trade that enters an exchange has to go through a Chinese broker (foreign brokers are prohibited from operating in China). This also creates responsibilities for brokers to ensure their members' compliance as rule violations would fall back on them. ${ }^{10}$ This setup, the so-called 'pass-through monitoring system', allows Chinese exchanges to trace every single trade to the original investor (and a Chinese ID card).

By deciding over available order types and acceptable levels of order (cancellation) and position limits, the Chinese exchanges also change the incentive structures for certain types of trading. The stock exchanges for instance introduced $t+1$ settlement and intraday trading is not possible, effectively preventing HFT. By keeping order (cancellation) limits low in futures markets, HFT is also limited as it often relies heavily on massive order flows/cancellations. This is not to say that HFT does not exist in China, but it is much more constrained than in global markets. ${ }^{11}$ Further, in both stock and futures markets, margins have to be pre-funded, and no portfolio margin offsetting exists in futures markets that would lower margins on large trading positions - another deliberate move to discourage speculation. 
Further, when trading in Chinese futures markets, traders have to indicate if trades are for hedging or speculative purposes. If investors have reached their position limit, additional orders will not be executed by an exchange's trading system. While position limits for 'spec' trades are higher for commodity futures, they are nonetheless restraining speculative trading. If an investor wants to trade more contracts, this is only possible for hedging purposes. Herefore, investors need to apply for hedging quotas with individual exchanges and contracts, where the need to hedge an underlying position must be sufficiently documented. For commodity futures for instance the investor needs to submit evidence for physical commodity deliveries at the respective commodity futures exchange, e.g. submit receipts of iron ore shipments. These hedging activities are monitored on a daily basis to prevent abuse. If there is a mismatch, e.g. an investor traded CSI 300 Futures worth RMB100 million for hedging purposes, but his equity position was only worth RMB80 million, the exchanges would punish such fraudulent behaviour. ${ }^{12}$

However, the exchanges sometimes also fail to achieve their goals as exemplified by the 2015 stock market crash. But even their management of such failures reveals a different way of managing markets as showcased by CFFEX's shutdown of the CSI 300 futures market. After being the world's most-traded equity index futures in 2015, it was killed over night after fears that it would exacerbate the stock market downturn. Between 25 August and 2 September 2015, CFFEX increased pre-fundable margins from 10 to 40 per cent, raised intraday execution fees 100 -fold to 23 basis points, lowered position limits from 500 to 10 contracts per day, investigated non-complying investors and suspended them from trading. As an interviewee who heads the China operations of a global exchange noted: 'That was incisive! Overnight the whole market and all that trading volume more or less collapsed by 99 per cent'. ${ }^{13}$ Such a market intervention through state institutions would be very unlikely and hardly possible in global finance (Figure 1).

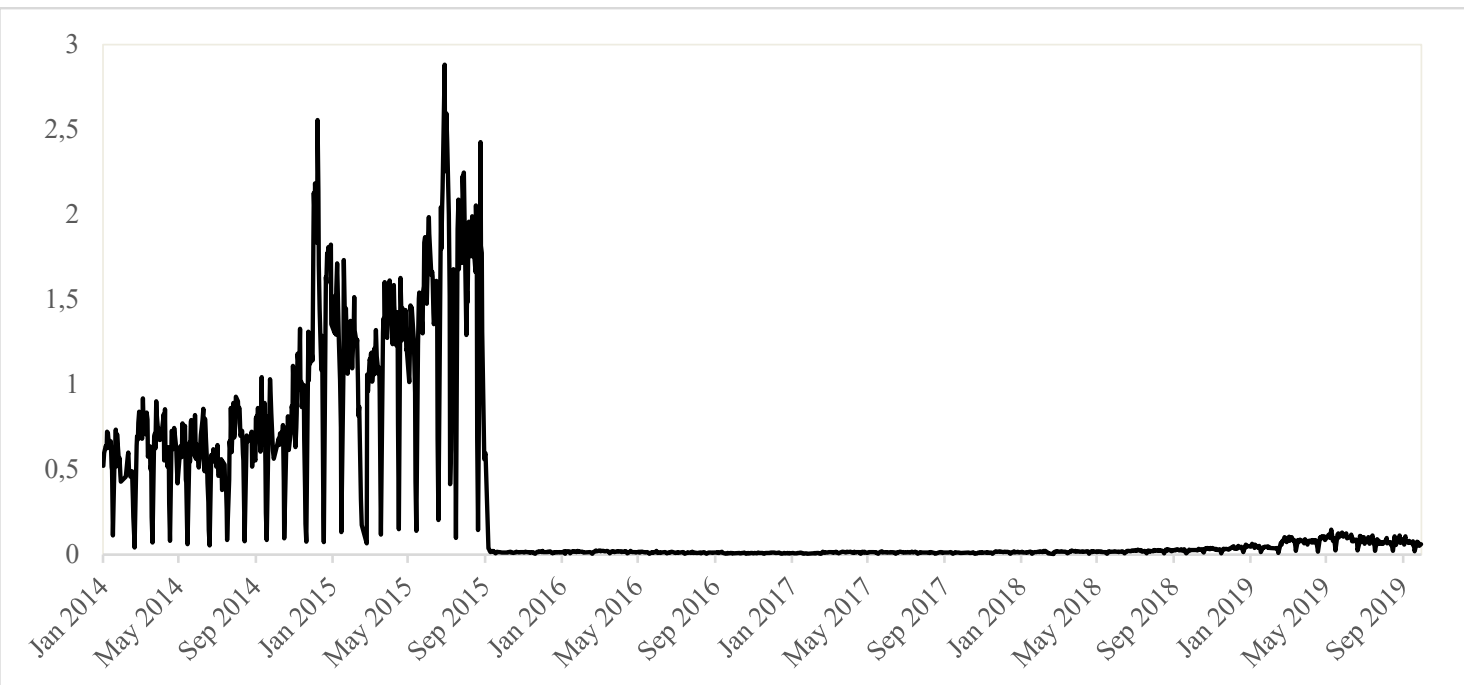

Figure 1 Daily trading volume for CSI 300 futures market, 2014-2019 (in million contracts; source: CFFEX trading data) 
The exchanges also constantly monitor trading activities in their 'transaction supervision departments', with the aim of detecting suspicious trading activities that could indicate market manipulation or insider trading. ${ }^{14}$ The stock exchanges monitor the trading of all listed stocks and regularly investigate whether accounts of market manipulation occur. When for instance a companies' stock quickly rises while trading volume does not rise accordingly, the exchange will suspect insider trading which can lead to an investigation by the exchange or the CSRC. The futures exchanges instead monitor certain core figures such as the trading volume to open interest ratio to determine whether illicit trading activities take place or whether there is 'overspeculation' in certain products. ${ }^{15}$ If there is too much speculative trading in a product, the exchanges will increase intra-day execution fees or intra-day margins for those contracts. Further, they will call top-traders or their brokers, telling them to stop trading for the day. As one former Chinese exchange employee told me: 'You have no idea how many calls I gave to these large accounts, telling them to stop trading! [...] But it's not written down anywhere, it's just window guidance'. ${ }^{16}$ This informal 'window guidance' is an important element of how exchanges manage markets.

Non-compliance can also be punished by the exchanges - trades can be annulled (or in rare cases even declared illegal), also retrospectively. Investors receive warnings and when violating rules repeatedly can even be banned from trading for a certain period or lose their trading licence all together. ${ }^{17}$ As one Chinese broker mentioned, 'when you read Futures Daily [a financial newspaper], every day there will be announcements of this or that company who has been suspended from trading because of rule violations, it happens every day'. ${ }^{18}$ As a consultant for Chinese exchanges noted, these harsh measures have a 'preventive/pre-emptive effect, stopping these things from happening in the first place' ${ }^{19}$ as (most) investors and brokers aim not to cross this line. Of course, this risk management is not always effective as demonstrated by the 2015 stock market crash. But failing to prevent overspeculation has severe consequences for exchange personnel. After the 2015 crash, for instance, several highlevel exchange and regulatory executives were ousted, most prominently CSRC Chairman Xiao Gang (see also Naughton, 2017). This demotion system aims to keep exchange employees 'vigilant' and not stray too far from their public mission. ${ }^{20}$

With a growing role of capital markets in China's economy, as a central feature of financialization processes speculation becomes ever more intense with potentially destabilising effects. Hence, the discussed measures are in place to prevent overspeculation, control the build-up of risk and alleviate tvolatility that is often seen as inherent to financialization. Of course, control is never absolute, and the exchanges sometimes fail at this task as demonstrated by the 2015 market crash. However, through exchanges the state aims to control some of financialization's negative repercussions. 


\section{Retail investors: stabilising the socio-political system}

Capital markets are also used as a way to facilitate social stability in China. In the absence of a sufficient public social security system and a simultaneous strain on the familial social security system due to the legacy of the one-child policy and a (consequently) aging population - investing into the stock market serves as a fix, facilitating the creation of a stock trading culture and a financialization of everyday life (Dal Maso, 2015). Already in the 1990s, slogans such as 'getting rich is glorious' animated millions of retail investors to invest into stocks (Walter and Howie, 2001). By now, the promise of a Chinese dream, socialism with Chinese characteristics and political stability are all intricately linked with the performance of the stock market. From less than 50 million trading accounts in 1999, more than 168 million trading accounts existed in the Chinese stock market alone by 2013 and 90 per cent of trading was conducted by these mom and pop investors. ${ }^{21}$ As a result, the performance of the stock market occupies a much more politically sensitive space than in many other countries. As one Hong Kong-based, former broker noted:

The authorities in mainland China don't want all their newly wealthy to be vulnerable to that type of activity. So, they are trying very hard to limit the damage that could be wreaked by sophisticated financial services practitioners on what are relatively inexperienced, knowledge-less new wealthy. ${ }^{22}$

As the literature on 'responsive authoritarianism' highlights, party-based authoritarian regimes such as China often rely upon support of a growing middle class to remain in power (Heurlin, 2016). ${ }^{23}$ Therefore, protecting retail investors is an important task for the exchanges. As many retail investors in China are notorious gamblers and their trading activity is often driven by rumours, the exchanges' above-mentioned system of risk monitoring and management is used in a delicate balancing act between allowing retail investors to participate in capital markets but also to reduce the volatility that they bring to markets and to protect them from themselves as well as more sophisticated investors. In a lot of interviews, retail investors were described as 'children', 'financially illiterate' and 'gamblers' who traded via their smartphones (often during their normal job), and needed to be protected from themselves (e.g. getting burned in market swings) and others (e.g. 'predatory' professional investors) by the paternal exchanges and regulators. As one interviewee working for a global exchange's China business development team put it:

\footnotetext{
I feel that the Chinese regulators are sometimes like parents, they have to take care of their little kid, retail investors are like the last, youngest, little kid. Whereas the institutions are relatively alright, the kid can be doing nonsense, he doesn't know what he's doing, he's not reasonable... But once he got hurt and then he's crying, the parent has to do something about it, right? ${ }^{24}$
}

The authorities do not want investors protesting on the streets because they lost money in the stock market. Therefore, as several Chinese exchange representatives noted in an 
interview, in order to protect retail investors, 'the biggest principle of China's [capital] market is fairness', ${ }^{25}$ and the capital markets organized by Chinese exchanges are designed to facilitate this objective - effectively acting as intermediaries between the Chinese state and society. To be clear, this was not always the case. As one Chinese hedge fund manager noted: '10-20 years ago, you could make a lot of money in the market with such business, manipulating prices et cetera. But now, the exchanges have developed and have much better systems. Back then, it was a jungle... it still is, but it's not so barbaric anymore. [...] I always advise friends to not do anything stupid, because [now] the Big Brother will know sooner or later'. ${ }^{26}$ After several scandals in the 1990s where for instance brokers misused client funds, exchanges started to extensively monitor brokers' activities and to clamp down on fraudulent behaviour such as market manipulations or insider trading.

As one Chinese private equity manager noted, '[today] some of the policy is actually more in favour of the retail investors than the institutionals' ${ }^{27}$ Stock exchanges for instance do not sell real-time market data which would give professional investors an advantage over retail investors. As mentioned, market data is instead published in bundles, which as one China-based foreign asset manager stated is 'good for lay people, but bad for professional investors' ${ }^{28}$ The stock exchanges also deliberately decided to stop intraday trading. On the one hand, this was established to keep retail investors from trading too much and to protect them from market movements. As an interviewee working for the international department of a Chinese exchange told me: 'Yes, we have $t+1$. [...] In the past we tried $t+0$, but you know... many retail investors will trade all the time... So, we introduced some limitation for them, [...]. The regulator thinks that with $\mathrm{t}+0$ we would add risk, [...] that some investors will trade too frequently, and it will not be good for the market'. ${ }^{29}$ On the other hand, this setup makes HFT trading impossible in the stock market, so sophisticated traders cannot gain an edge over lay traders. Similarly, exchanges require companies to make announcements that have an impact on share prices after trading hours. In contrast to global markets, where announcements need to be made asap, the rationale in China is to not disadvantage retail investors as these usually work during trading hours and can therefore not react to this information. ${ }^{30}$

The exchanges also have policies in place to protect retail investors from themselves, by for instance facilitating investor professionalization and conducting/ sponsoring many training and education activities. As Wójcik (2012, p. 121) noted in his analysis of the Warsaw Stock Exchange, one important activity of exchanges is to 'educate investors [...] which is particularly important in the context of a country where stock market did not exist for over half a century before 1991'. Consequently, brokers that want to host marketing events can apply for funding from exchanges, under the condition that they also provide such educational sessions. ${ }^{31}$ In order to trade index futures or options, the exchanges also require investors to take exams, so that they gain a better understanding about what they are trading (and to reduce trading by 
uninformed investors). Further, the exchanges attempt to make it harder to access certain market segments by introducing high entry requirements. Investors participating in the Hong Kong Stock Connect for instance need to hold an aggregate balance of at least RMB 500,000 in their account (HKEx, 2019) and when designing the new internationally accessible crude oil contract, the contract specifications were altered from 1,000 to 10,000 lots - i.e. increasing the price 10 -fold - in part to prevent too much retail participation. ${ }^{32}$

Overall, capital markets play an important role in the social fabric of Chinese authoritarian capitalism. In the interest of harmony and social stability, retail investors were both encouraged to participate in the market but also needed to be protected from severe losses and unfair market practices. However, this created political risks for the authorities. Here, the Chinese exchanges play an important role in this balancing act, managing and directing financialization to mitigate the relationship between the Chinese state, society and capital markets in its transition towards a more financialized political economy.

\section{Real economy: assessing the social usefulness of finance}

Another important aspect of financialization processes is the relationship between finance and the real economy. In the financialization literature, many scholars highlight that increasing financialization often negatively affects real economic development (Krippner, 2005; Stein, 2011). What can be observed in the actions of Chinese exchanges are attempts to mitigate this development. One phrase that is often invoked by Chinese authorities is that 'finance should serve the real economy', 33 a notion that was reinforced in 2015 when $\mathrm{Xi}$ Jinping emphasized that 'serving the real economy is the bounden duty and purpose of the financial sector'. ${ }^{34}$

Consequently, assessments about the social usefulness of financial trading are made. Financial derivatives for instance are viewed with a lot of suspicion by the authorities and strict rules apply. While similar rules exist for commodity derivatives, they are not quite as stringent because the authorities believe that they better serve the real economy as companies (might) use them for hedging purposes instead of speculation. ${ }^{35}$ The Chinese exchanges try to ensure this through their contract specifications; strict position limits and hedging quotas play an important role here (discussed above). Further, almost all contracts on Chinese futures exchanges need to be physically delivered. ${ }^{36}$ This is in stark contrast to international markets where almost all contracts are cash settled as there is no mandate or interest to actively encourage actual commodity trading. ${ }^{37}$ The Chinese exchanges also engage in many educational activities to get commodity companies, e.g. steel mills, mining, energy or foodprocessing companies to hedge their risk in commodity markets. ${ }^{38}$ 
Chinese exchanges are also aiming to assist national development goals by facilitating China's (commodity) pricing power. As commodity futures prices are used as reference points for physical trading, the Chinese exchanges aim to gain sufficient market share to gain benchmark status and thereby have a say in the global pricing of commodities. Free market advocates argue that these prices are set by markets and that it is 'absurd' that China wants to have a 'say' in commodity pricing. ${ }^{39}$ However, from a national development perspective, this makes sense as prices created in Chinese markets would better reflect local demand and supply rather than prices determined in the United States where Chinese companies felt they had to pay a premium. As the China business development team of a global exchange noted:

Every five years they need to agree on a price with the Australian iron ore producer backed by the Western buying power, and they always got very ripped off in the negotiations, you know, because you have to mark reference to the market price and the market didn't take place anywhere near you, it takes place globally... so, that's something the government is putting focus on. ${ }^{40}$

Having their own benchmarks would give Chinese companies 'better' prices than the global prices they have to accept otherwise - which are set in Chicago, New York and London. Further, as the research department of a Chinese exchange noted, Chinese companies and authorities have 'no good relations to the Fed and financial officials in the US'; ${ }^{41}$ but if these markets were situated in China and regulated by Chinese exchanges, the authorities could exert more control over them. Hence, to gain commodity pricing power the Chinese exchanges carefully made strategically important commodity contracts (crude oil, iron ore, PTE) accessible to international investors. A year after being launched in March 2018, the Shanghai crude oil contract for instance gained a market share of 16 per cent in global oil futures markets, displacing Dubai as the world's third-largest benchmark, while the market shares of WTI and Brent dropped from 60 to 52 per cent and from 38 to 32 per cent, respectively (Evans, 2018). As Fang Xinghai, Vice Chairman of the CSRC, noted in 2016: '[China] is facing the chance of a lifetime to become a global pricing center for commodities [...] it would be a "historic mistake" not to grasp [this] rare opportunity' (cited in Tan, 2017).

A similar rationale explains China developing an onshore financial futures market. In an effort to develop Chinese financial services, in 2000 a joint venture between FTSE and Xinhua Finance was established to create indices on Chinese stocks (A-shares). But unbeknownst to the Chinese authorities, FTSE-Xinhua signed an agreement with Singapore Exchange (SGX), licensing an index to create a financial futures contract. ${ }^{42}$ While initially disregarding the contract, as it started gaining traction, the Chinese authorities became increasingly concerned. Domestic stock markets started to behave weirdly - more and more often stock prices in China were driven by the futures contract traded in Singapore; the tail was wagging the dog. Suddenly, these 'A50 Futures had pricing power over the A-shares market'. ${ }^{43}$ As Euromoney noted, there was 
'an uneasiness in China at the idea that derivatives on Chinese stocks and instruments can be traded somewhere else in the world with absolutely no control from the People's Republic itself' (emphasis added; Wright, 2006). As immediate response, Shanghai Stock Exchange (SSE) sued SGX for using its market data. But more importantly, this facilitated the development of Chinese onshore financial futures. As the research department of a Chinese exchange noted, the (previously discussed) 'CSI 300 was a reply to the A50 Futures, the A50 pushed forward the Chinese government to make a quick decision'. ${ }^{44}$ While the Chinese authorities were originally against building domestic financial futures markets after the failure of bond futures in the 1990s, the success of the offshore A50 contract forced the creation of CFFEX and a Chinese index futures market. When CSI 300 futures were launched in 2010, the process had been sped up significantly in order to regain control. With their own contract in place, the Chinese exchanges could manage their domestic markets instead of letting a foreign exchange decide the rules of the game and let foreign speculators distort their domestic stock markets.

Overall, there is an assessment of the social usefulness of finance (financial vs commodity futures) and how it can contribute to (commodity pricing) - or at least not interfere with (SGX-A50) - the real economy and national economic development. The actions of China's exchanges aim to facilitate such policy outcomes, in an attempt to offset some of the negative consequences of financialization processes which often disadvantage the real economy vis-à-vis finance.

\section{Reform: restructuring China's companies}

The liberalization and opening of financial markets have been part of a larger trend in China towards allowing a greater role for markets in its economy, including the governance of Chinese companies. In global capital markets, the premise of a listing is a transfer of control (i.e. ownership) in return for funding. However, this often significantly changes the incentives and behaviour of listed companies, exemplified by the move towards shareholder value orientation (Aglietta and Breton, 2001; Williams, 2000). In China, the political-economic function of capital markets for listed companies however differs. Instead of raising funds, capital markets rather helped to reform Chinese companies while maintaining control over them by reforming SOEs and facilitating their international standing and recognition. The exchanges facilitate these reform processes by acting as intermediaries between the Chinese state and listed companies.

While internationally the main function of stock markets is for companies to raise money, most exchange-listed companies in China are state-owned enterprises (SOEs) with sufficient funding from state-owned banks. The state's role is also not diminished through the (often only partial) listing of SOEs - its control instead changed from direct ownership to often becoming the largest shareholder (see Y. Wang, 2015). 
But as a result of partial listings, Chinese SOEs became more efficiently run, less wasteful companies, adopting 'modern' corporate governance structures and receiving knowhow from strategic international investors. As a Frankfurt-based exchange representative noted, 'you know, the purpose of stock markets in China was to reform SOEs'. ${ }^{45}$ In the form of 'publicly' listed companies, these Chinese companies gained a certain legitimacy in international markets. ${ }^{46}$ Getting listed in China is a lengthy process with many administrative hurdles and strict requirements and whoever gets listed has a 'seal of approval' from the government which enables them to engage in global M\&A activities with somewhat less scrutiny, as a managing partner of a Beijing-based law firm noted. ${ }^{47}$ Overall, listing companies was a way of grooming national champions and to facilitate a national development strategy (Heilmann, 2008).

The Chinese stock exchanges were vital in this process: educating companies about international best practice, setting corporate governance standards for listed companies and monitoring compliance with these standards. ${ }^{48}$ While companies might not fully follow these rules, significant discrepancies or violations will be picked up by the exchanges' investigation teams. As a Chinese regulator stated, 'if they didn't do that [follow window guidance], the result could be disastrous... they might be investigated more often, the exchanges would take a closer look at the board... [...] companies don't want the regulators to pay attention' ${ }^{49}$

This monitoring and intervening role of the exchanges could also be observed during the $\mathrm{MSCl}$ inclusion process. ${ }^{50}$ After years of consultations and negotiations, in June 2018, index provider $\mathrm{MSCl}$ decided to include Chinese A-share stocks into its indices, triggering estimated investment flows of USD80bn into Chinese capital markets (Wright, 2019). This represented a milestone for China's opening process. It was enormously prestigious for the Chinese authorities and an 'accolade' that showed China's increased recognition in the international investment community; the head of a global bank's European FX trading desk likened it to 'basically China's ascent into the Champions League'. ${ }^{51}$ However, preconditions were that included shares could be traded by foreign investors relatively freely (accomplished through the Stock Connects; next section) and that included companies meet $\mathrm{MSCl}^{\prime}$ s corporate governance standards. Thereby, Chinese exchanges 'would also brief companies before $\mathrm{MSCl}$ came to visit them, so that they knew what to tell $\mathrm{MSCl}^{\prime},{ }^{52}$ as well as hosting multiple events to educate companies about how to comply with $\mathrm{MSCl}$ 's governance framework. ${ }^{53}$

In contrast to neoliberal norms of financialization, in China neither has shareholder value orientation taken over nor state control been undermined. An open question remains whether this process also created the conditions for other (potentially negative) developments, as this enabled cash-rich listed companies to engage in trophy purchases or to evade solvency constraints. ${ }^{54}$ Overall, capital markets played an important role in helping to restructure China's economy and raise the international recognition and competitiveness of its companies. By monitoring and facilitating capital 
market development, the Chinese exchanges helped to manage the reform of China's companies within this financialization process.

\section{Maintaining control... despite international investors}

Another important characteristic of financialization processes is the integration with global markets and investors. In the financialization literature, the ability of international investors to withdraw their funds is often described as a disciplinary mechanism in case countries do not follow a neoliberal rulebook (Bortz and Kaltenbrunner, 2018; Hardie, 2012). But while China's capital markets have been increasingly accessible for international investors (Li, 2018a), instead of opening the floodgates China's financial opening enables foreign investor participation while maintaining state control. The exchanges hereby act as intermediaries between the Chinese state and global finance.

The Chinese authorities have an ambiguous relationship with global investors. As the CEO of a Hong-Kong based asset manager stated, 'it's absolutely a love and hate story, they love the money, love the stability, hate giving up control... and hate it if foreign investors want to dominate the terms' ${ }^{55}$ On the one side, foreign investor participation helps to professionalize China's financial industry which is crucial for its aspirations to becoming a global financial powerhouse. When talking about international proprietary trading firms operating in China, one Shanghai-based foreign asset manager noted: 'Optiver did not fight its way into China, they are tolerated by the exchanges, the authorities - and Optiver pays with its know-how. [...] I am sure they must employ only Chinese people who learn from them' ${ }^{56}$ International players are let in to train/educate local firms, making them fit for global markets, a logic similar to listing SOEs in order to create globally competitive national champions (Heilmann, 2008). On the other side, the authorities are wary of losing control over markets through an increasing influx of foreign money. ${ }^{57}$ Especially as maintaining capital controls, controlling its currency exchange rate and financial system are core pillars of the Chinese economies' authoritarian governance. Therefore, the Chinese exchanges organize market infrastructures that enable foreign investor participation while simultaneously maintaining control over their markets.

While foreigners are not allowed to freely participate in Chinese markets, they

can access Chinese markets in a controlled manner. ${ }^{58}$ Foreign companies are allowed to access markets if they establish local entities, co-called wholly foreign-owned enterprises (WFOEs). What seems like a creative way around Chinese regulations that ban foreigners from trading, setting up WFOEs is accepted by the authorities - because these companies are registered in China and therefore subject to Chinese laws and regulatory control. ${ }^{59}$ The authorities decide who gets WFOE licenses, the process is very thorough, WFOEs cannot easily expatriate their funds/profits (capital controls), and the regulators define which of their activities are legitimate. Because it is a grey area, the 
regulators always have 'probable cause' 60 against these foreign investors - which are ideal scapegoats to deflect the anger of afflicted Chinese retail investors during a market downturn. Instructive here is the case of Russian trading firm Yishidun International Trading whose trading on CFFEX was retroactively declared illegal, had to pay a considerably fine and was banned from trading indefinitely. ${ }^{61}$ So, although all the world's large financial players are active in Chinese markets, monitored by the exchanges they have to play according to Chinese rules. In contrast to global markets, they are at the very bottom of the food chain.

When it comes to trading into China from abroad, even more restrictions apply and the mechanisms that are in place to enable trading in and out of China are quite different from international markets. As the emerging markets strategist of a global exchange noted:

I have an analogy... [...] If you look at capital controls as a wall, people have eliminated them in different ways... and you can remove the wall, full liberalization, Big Bang, and that has a whole range of problems... you can remove it gradually... or you can do what the Chinese are doing and build holes through it. [...] You build holes and then you think you can repair them if needed, and you leave the height of the wall more or less intact. ${ }^{62}$

The first such mechanisms were the QFII and RQFII investor schemes in 2003, where investors had to apply for quotas (see Töpfer, 2017). However, the real turning point in opening up Chinese markets was the establishment of the Stock Connects between Hong Kong, Shanghai and Shenzhen in 2014/2016. Basically, the Stock Connect enables traders who can access HKEx to trade stocks on SSE via HKEx, and vice versa. ${ }^{63}$ However, for the Connects, 'home-rules' apply. International investors in Hong Kong must adhere to the previously identified characteristics of Chinese markets such as limited order types, data availability or $\mathrm{t}+1$ (no intra-day trading). Further, as of September 2018, the 'pass-through monitoring system' to identify individual investors was also applied to the Stock Connect, so that Chinese exchanges can now monitor the trading activities of every single international investor trading China through the Connects, a massive departure from international practice. ${ }^{64}$

The Connect Schemes are also 'closed loops'. This means that if mainland investors invest in HKEx-listed shares through the Connect and decide to sell these, the resulting HKD-denominated proceeds get transferred into RMB and channelled back to the investor's mainland account (and vice versa). So, while order routing and transaction flows between the two markets are enabled, capital controls remain completely intact. In addition, if trading gets too wild, the exchanges can restrict trading. As HKEx's group strategy department stated, 'with Stock Connect you have this beautiful sort of capital control mechanism [...] they [the Chinese exchanges] can always turn off the tap... ${ }^{65}$ The Stock Connects are hence designed by Chinese exchanges to simultaneously open their 
markets to global investors, while maintaining their market monitoring and surveillance machinery as well as capital controls.

This controlled international integration of China's capital markets is also a key point in the US-China trade war negotiations, where the United States is trying to facilitate a more encompassing opening of China's financial system. As a response, the Chinese authorities have liberalized some aspects of their markets, especially removing foreign ownership caps on certain financial institutions. However, even if foreign investors can soon fully own brokers and asset managers, these foreign firms are still registered in China, subject to capital controls and must adhere to the rules set out by Chinese exchanges the same way as Chinese entities or WFOEs. ${ }^{66}$ As one Chinese broker noted, '[while] the regulations have been changing in the last two years, what is not changing is the infrastructure. [...] Yes, the regulation is seemingly becoming more international, [but] they will never change the infrastructure because this is where they can exercise the power' ${ }^{67}$ This was also confirmed by a Chinese regulator's research department who noted that while there is 'closer alignment towards international practices' with respect to financial regulations resulting from the trade war, 'the infrastructural arrangements stay the same - because this is where you can control the market!' 68 From this perspective, while accelerating the opening up process, the current 'concessions' made by the Chinese government do not represent a break with the preexisting path.

So, while Chinese capital markets are increasingly integrated with global markets, Chinese exchanges govern these markets quite differently, forcing international investors to play according to Chinese rules, hence maintaining state control within capital markets despite an increasingly contested opening process.

\section{Conclusion: the politics of variegated financialization in China's authoritarian capitalism}

While one can observe an increasing financialization in China, this process unfolds within the context of China's authoritarian capitalism. This paper analyzed the development of China's capital markets and how Chinese state-owned exchanges engage in processes of market management, thereby acting as intermediaries between the Chinese state, society and finance. Rather than a break with China's authoritarian capitalism, the activities of Chinese exchanges help to sustain and facilitate China's existing socioeconomic system through steering the financialization process. As a result, Chinese capital markets function quite differently from 'global' markets, as they are organized with controlling markets and directing their outcomes towards state policies as their underlying principles. The active management of capital markets through Chinese exchanges addresses different parts of China's socio-economic system and aim to: prevent the building up of excessive financial risks (financial sector); stabilize the socio- 
political system by simultaneously encouraging and protecting retail investor participation (society); assess the usefulness of financial activities and their contribution to the real economy (national development); and assist in the reform of Chinese corporations (non-financial sector); while maintaining control despite an increased opening to international investors. Rather than enforcing relative conformity with a neoliberal hegemonic project (Carroll and Jarvis, 2014), within the variegated financialization of China's political economy exchanges sustain and facilitate the development of Chinese authoritarian capitalism.

The findings of this paper are still somewhat stylized. Processes on the ground are often more chaotic, control over capital markets is neither complete nor always effective as the 2015 stock market crash demonstrated. Future research is therefore needed to more closely assess the degree and effectiveness of these control measures, how these vary across different segments of China's authoritarian capitalism and how they interact with global financial arrangements. It is important to note that even if actively facilitated to create economic growth and partially steered by the state, like any financialization process, China's variegated financialization is still inherently crisisprone, creates new contradictions, and some effects of financialization such as rising wealth and income inequality or a financialization of everyday life severely affect Chinese society. However, this paper rather aims to showcase the development of a different way of thinking about and managing of capital markets in China where the state attempts to steer and shape parts of China's variegated financialization which is not necessarily linked to neoliberalism but unfolds within the context of authoritarian capitalism. And while many political economy scholars would surely welcome such restraints of unfettered 'global' finance, it is important to note that in the Chinese case this process is integrally linked to other elements of China's political and socio-economic system whose implementation many would probably not support.

Contributing to the literatures on variegated financialization and the state, this paper argues that states cannot only be important actors that facilitate financialization, but that they can also exercise a considerable degree of control over specific aspects of financialization processes, shaping their very form and political outcomes. In the Chinese case, that exchanges are state-owned has important consequences for how they manage capital markets, facilitating the state-controlled nature of financialization within the context of China's authoritarian capitalism. By highlighting the role of exchanges as 'pivotal points' for managing capital markets, this paper also contributes to the growing literature on the importance of market actors and infrastructures in finance (Bernards and Campbell-Verduyn, 2019). Building on this single case study, future research could investigate whether such state-controlled processes of financialization also exists in other countries where the state maintains a strong role within the economy (Nölke et al., 2019). Such an analysis could shed light on whether this is a uniquely Chinese phenomenon, intrinsically linked to an authoritarian political 
system, or a question of state capacity. This could further contribute to ongoing debates on convergence, models of capitalisms and trajectories of financialization.

Since the GFC, China has become the world economy's engine, accounting for 45 per cent of global GDP growth (The Economist, 2018). Its capital markets have developed and internationalized to an unprecedented degree, turning China into an important player in global finance, but one that plays according to its own rules. This situation has created rising tensions, especially with the United States, culminating in the current US-China trade war. A large point of contention in these negotiations is the opening up of China's financial markets. However, while Chinese financial regulations seem to approach international norms, the infrastructural arrangements that enable the Chinese authorities to manage capital markets have remained unchanged. From this perspective, the 'concessions' made by the Chinese government do not deviate from the pre-existing path of gradually opening up its markets while maintaining control. In the face of this systemic competition between different ways of organising financial and economic life, more research is required to understand the mechanisms, form and content of this financialization with Chinese characteristics and its place within China's authoritarian capitalism.

\section{Notes}

1. Measured by the ratio of stocks traded to credit provision as per cent of GDP; see Karwowski and Stockhammer (2017).

2. In comparison, for the United States (2014-2017) the average market- versus-bank activity was 0.93 , the value of stocks traded 220.8 per cent and market capitalization 150.5 per cent of GDP (World Bank, 2018). The United States accounted for 33 per cent of global futures market trading (FIA, 2017) and finance/insurance contributed 7.5 per cent to it's GDP (https://www.selectusa.gov/financial-services-industry-united-states).

3. Interview: Chinese hedge fund manager (Shanghai, 16/04/2018).

4. This finding is in line with Gruin's (2019b) analysis of China's digital credit scoring which he describes as another way 'in which advances in financial technology open up new opportunities for socio-economic "development" as well as the exercise of political authority'.

5. Interview: China, 05/07/2017.

6. Interview: research department of exchange (China, 18/10/2018).

7. On the significance of policy experimentation for China's economic development, see Heilmann (2008).

8. Interview: Hong Kong, 26/09/2018.

9. Observation: 'Global exchange leaders' panel, FIA Asia Derivatives Conference (Singapore, 29/11/2017).

10. Interview: Chinese hedge fund manager (Shanghai, 16/04/2018).

11. Interview: international department of Chinese broker (Shanghai, 26/04/2018).

12. Interview: Chinese hedge fund manager (Shanghai, 16/04/2018). 
13. Interview: Hong Kong, 30/07/2017.

14. Interview: research department of regulator (Beijing, 30/10/2018).

15. Interview: consultant of Chinese exchange (Shanghai, 09/05/2018).

16. Interview: Beijing, 07/11/2018.

17. Interview: international department of international broker (Hong Kong, 26/09/2018).

18. Interview: international department of Chinese broker (Shenzhen, 18/05/2018).

19. Interview: Beijing, 29/10/2018.

20. Interview: research department of exchange (China, 18/10/2018).

21. Speech: CSRC chairman Guo Shuqing 'To develop a more open and inclusive capital market in China', Asian Financial Forum (Hong Kong, 14/01/2013).

22. Interview: Hong Kong, 06/07/2017.

23. Sum (2019) refers to this as 'performance legitimacy'.

24. Interview: Hong Kong, 07/07/2017.

25. Interview: Shanghai, 11/05/2018.

26. Interview: Shanghai, 24/09/2019.

27. Interview: Hong Kong, 22/07/2017.

28. Interview: Shanghai, 15/05/2018.

29. Interview: Shanghai, 26/04/2018.

30. Interview: emerging markets strategist of global exchange (London, 11/01/2018).

31. Interview: Chinese hedge fund manager (Shanghai, 16/04/2018).

32. Observation: 'Crude oil and building international pricing' panel, FOW Derivatives World Asia Conference (Hong Kong, 11/04/2018).

33. This was prominently discussed at the Third Plenary Session of the 18th Central Committee of the Communist Party of China (12/11/2013).

34. Speech: 5th National Financial Work Conference (Beijing, 14/07/2017).

35. Interview: derivatives department of Chinese broker (Hangzhou, 24/04/2018).

36. Only index futures are cash settled, even bond futures and options are physically delivered.

37. Interview: department head of commodity trading platform (Hangzhou, 22/04/2018).

38. Observation: Iron Ore Futures Internationalization Symposium (Dalian, 15/10/2018).

39. Interview: consultant of Chinese exchange (Shanghai, 09/05/2018).

40. Interview: Hong Kong, 07/07/2017.

41. Interview: China, 18/10/2018.

42. Interview: business development of index provider (Hong Kong, 27/09/2018).

43. Interview: research department of exchange (China, 18/10/2018).

44. Interview: China, 18/10/2018.

45. Interview: business development of exchange (Frankfurt, 02/02/2018).

46. Interview: managing partner of Chinese law firm (Beijing, 18/10/2018).

47. Interview: Beijing, 18/10/2018.

48. Interview: research department of regulator (Beijing, 31/10/2018).

49. Interview: research department of regulator (Beijing, 30/10/2018).

50. On China's MSCl inclusion and the politics of index inclusions, see Petry et al. (2019).

51. Interview: Frankfurt, 25/01/2018.

52. Interview: research department of regulator (Beijing, 30/10/2018).

53. Interview: international department of exchange (Shanghai, 26/04/2018).

54. I thank a reviewer for mentioning this point. 
55. Interview: Hong Kong, 28/07/2017.

56. Interview: managing partner of asset manager (Shanghai, 15/05/2018).

57. Interview: Chinese private equity firm (Hong Kong, 22/07/2017).

58. Interview: managing partner of Chinese asset manager (Shanghai, 15/05/2018).

59. Interview: research department of Chinese exchange (Shanghai, 14/05/2018).

60. Interview: consultant of Chinese exchange (Shanghai, 08/05/2018).

61. Interview: business development department of global exchange (Hong Kong, 24/07/2017).

62. Interview; London, 11/01/2018.

63. In addition, the Hong Kong-China Bond Connect was launched in 2017.

64. Overall, Hong Kong is an important gateway and facilitator of China's opening process (Li, 2018b).

65. Interview: Hong Kong, 30/07/2017.

66. In addition, foreign firms would have difficulties attracting business from Chinese retail investors; interview: managing director of commodity trading platform (China, 25/10/2019).

67. Interview: Beijing, 12/09/2019.

68. Interview: Beijing, 12/09/2019; also, interview: Chinese hedge fund manager (Shanghai, 24/09/2019). 


\section{References}

Aglietta, M. \& Breton, R. (2001).

Financial systems, corporate control and capital accumulation. Economy and Society, 30(4), 433-466.

Ahrne, G. Aspers, P. \& Brunsson, N. (2015). The organization of markets. Organization Studies, 36(1), 7-27.

Bernards, N. \& Campbell-Verduyn, M. (2019). Understanding technological change in global finance through infrastructures. Review of International Political Economy, 26(5), 773-789.

Bonizzi, B. (2013). Financialization in developing and emerging countries. International Journal of Political Economy, 42(4), 83-107.

Bortz, P. G. \& Kaltenbrunner, A. (2018). The international dimension of financialization in developing and emerging economies. Development and Change, 49(2), 375-393.

Carroll, T. \& Jarvis, D. S. L. (2014). Introduction: Financialisation and development in Asia under late capitalism. Asian Studies Review, 38(4), 533-543.

Castelle, M. Millo, Y. Beunza, D. \& Lubin, D. C. (2016). Where do electronic markets come from? Regulation and the transformation of financial exchanges. Economy and Society, 45(2), 166-200.

Chong, K. (2018). Best practice: Management consulting and the ethics of financialization in China. Durham: Duke University Press.

Collins, N. \& Gottwald, J.-C. (2014). Market creation by Leninist means: The regulation of financial services in the
People's Republic of China. Asian Studies Review, 38(4), 620-638.

Dal Maso, G. (2015). The financialization rush: Responding to precarious labor and social security by investing in the Chinese stock market. South Atlantic Quarterly, 114(1), 47-64. Dixon, A. D. (2011). Variegated capitalism and the geography of finance: Towards a common agenda. Progress in Human Geography, 35(2), 193-210.

Epstein, G. A. (2005). Introduction: Financialization and the world economy. In G. A. Epstein (Ed.), Financialization and the world economy (pp. 3-16). Cheltenham: Edward Elgar. Evans, D. (2018, October 17). Shanghai shakes up global oil trading. Nikkei Asian Review.

FIA (Futures Industry Association). (2017). FIA global exchange volume dataset.

Brussels/Singapore/London/Washingto nD.C.: Futures Industry Association. Gabor, D. (2018). Goodbye (Chinese) shadow banking, hello market-based finance. Development and Change, 49(2), 394-419.

Gruin, J. (2016). The social order of Chinese capitalism: Socio-economic uncertainty, communist party rule and economic development, 1990-2000. Economy and Society, 45(1), 24-50. Gruin, J. (2019a). Communists constructing capitalism: State, market, and the party in China's financial reform. Manchester: Manchester University Press. 
Gruin, J. (2019b). Financializing

authoritarian capitalism: Chinese

fintech and the institutional

foundations of algorithmic governance.

Finance \& Society, 5(2), 84-104.

Hardie, I. (2012). Financialization and

government borrowing capacity in

emerging markets. Basingstoke:

Palgrave Macmillan.

Heilmann, S. (2005). Regulatory

innovation by Leninist means:

Communist Party supervision in China's

financial industry. The China Quarterly,

181(March), 1-21.

Heilmann, S. (2008). Policy

experimentation in China's economic

rise. Studies in Comparative

International Development, 43(1), 1-26.

Heurlin, C. (2016). Responsive

authoritarianism in China. Cambridge,

UK: Cambridge University Press.

HKEx. (2019). Shanghai connect,

Shenzhen connect. Information book for

investors. Hong Kong: Hong Kong

Exchanges and Clearing Limited.

Huang, Z. \& Lardy, N. R. (2016, January

5). Financial services in China. Peterson

Institute for International Economics.

Retrieved from

https://piie.com/blogs/china-

economic-watch/financial-services-

china.

Karwowski, E. \& Stockhammer, E.

(2017). Financialisation in emerging

economies: A systematic overview and

comparison with Anglo-Saxon

economies. Economic and Political

Studies, 5(1), 60-86.

Krippner, G. R. (2005). The

financialization of the American economy. Socio-Economic Review, 3(2),

173-208.

Lapavitsas, C. \& Powell, J. (2013).

Financialisation varied: A comparative

analysis of advanced economies.

Cambridge Journal of Regions, Economy and Society, 6(3), 359-379.

Li, Y.-W. V. (2018a). China's financial opening: Coalition politics and policy changes. London: Routledge.

Li, Y.-W. V. (2018b). Hong Kong in China's financial globalization: Market power and political leverage. Asian Survey, 58(3), 439-463.

Lu, J. \& Sweeney, P. (2012, November 13). China's total social financing data since 2002. Reuters.

Lyu, K. (2015). The institutional transformation of China's stock exchanges: A comparative perspective. Accounting, Economics and Law: A Convivium, 5(1), 1-47.

MacKenzie, D. (2006). An engine, not a camera. Cambridge, MA: MIT Press.

MacKenzie, D. (2018). 'Making', 'taking' and the material political economy of algorithmic trading. Economy and Society, 47(4), 501-523.

McNally, C. A. (2013). The challenge of refurbished state capitalism: Implications for the global political economic order. dms - der moderne staat, 6(1), 33-48.

Naughton, B. (2017). The regulatory storm: A surprising turn in financial policy. China Leadership Monitor, 53, 1-12.

Nölke, A. ten Brink, T. May, C. \& Claar, S. (2019). State-permeated capitalism in large emerging economies. London: Routledge. 
Pauls, R. Andreosso-O'Callaghan, B. \&

Gottwald, J.-C. (2016). On a path

towards financialization? The

expanding role of finance in China's

growth regime. In B. Zolin, B.

Andreosso-O'Callaghan \& J. Jaussaud

(Eds.), Economic change in Asia:

Implication for corporate strategy and social responsibility (pp. 29-47).

London: Routledge.

Petry, J. (2020). Securities exchanges:

Subjects \& agents of financialization. In

D. Mertens, P. Mader \& N. van der

Zwan (Eds.) The Routledge

International Handbook of

Financialization (pp. 253-264). London:

Routledge.

Petry, J., Fichtner, J. \& Heemskerk, E.

(2019). Steering capital: The growing

private authority of index providers in

the age of passive asset management.

Review of International Political

Economy. Advance online publication.

Pike, A. \& Pollard, J. (2010). Economic geographies of financialization.

Economic Geography, 86(1), 29-51.

Rethel, L. \& Thurbon, E. (2019).

Introduction: Finance, development

and the state in East Asia. New Political

Economy. Advance online publication.

Sigley, G. (2006). Chinese

governmentalities: Government, governance and the socialist market economy. Economy and Society, 35(4), 487-508.

Stein, J. (2011). Pivotal decade: How the United States traded factories for finance in the seventies. New Haven, CT: Yale University Press.

Strange, S. (1998). Mad money: When markets outgrow government.
Manchester: Manchester University Press.

Sum, N.-L. (2019). Ordoliberal authoritarian governance in China since 1978: World market, performance legitimacy, and biosovereign ordering. South Atlantic Quarterly, 118(2), 381400.

Tan, H. (2017, March 4). China is now calling the shots in metals pricing. CNBC.

ten Brink, T. (2019). China's capitalism. A paradoxical route to economic prosperity. Philadelphia: University of Pennsylvania Press.

The Economist. (2018, October 27). The Chinese century is well under way.

Theurillat, T. Lenzer, J. H. J. \& Zhan, H. (2016). The increasing financialization of China's urbanization. Issues \& Studies, 52(4), 1-37.

Thurbon, E. (2016). Developmental mindset: The revival of financial activism in South Korea. Ithaca, NY: Cornell University Press.

Töpfer, L.-M. (2017). Institutional change in Chinese cross-border finance: Foreign investors, the party-state and power resources. Review of International Political Economy, 24(1), 144-175.

Tsai, K. S. (2015). The political economy of state capitalism and shadow banking in China. Issues \& Studies, 51(1), 55-97. Walter, C. E. \& Howie, F. J. T. (2001). To get rich is glorious! China's stock markets in the '80s and '90s. Basingstoke: Palgrave Macmillan. Wang, J. (2017). 'Stir-frying" internet finance: Financialization and the institutional role of financial news in 
China. International Journal of

Communication, 11, 581-602.

Wang, J. (2018). Inclusion or expulsion:

Digital technologies and the new power relations in China's 'internet finance'.

Communication and the Public, 3(1),

34-45.

Wang, Y. (2015). The rise of the

'shareholding state': Financialization of economic management in China. SocioEconomic Review, 13(3), 603-625.

Williams, K. (2000). From shareholder value to present-day capitalism.

Economy and Society, 29(1), 1-12.

Wójcik, D. (2012). The global stock

market: Issuers, investors, and intermediaries in an uneven world.

Oxford: Oxford University Press.

World Bank. (2018). World

development indicators. World Bank

Group.

Wright, C. (2006, September 29). SGX

FTSE Xinhua China index: Control of the futures. Euromoney.

Wright, C. (2019, March 1). MSCI China reweighting a big deal - but not that big. Euromoney.

Yang, Y. (2017, March 13). Clampdown puts brakes on Chinese house price boom. The Financial Times. 